\title{
Venezuelan scientists speak out
}

\section{University cuts are the latest in a series of government actions that have researchers seeing red.}

Research in Venezuela, already battered on many fronts, faces budget cuts that have in recent weeks triggered students to protest and others to complain that the country's science infrastructure is approaching collapse.

Venezuela's finances depend heavily on the price of oil, which other than a recent rise has for months been below the US $\$ 60$ per barrel that the government counted on when it drew up the national budget. As a result, Venezuelan President Hugo Chávez signed a decree that in March ordered government-funded institutions to reduce their 2009 spending by $6 \%$. The cut came after five years of flat financing amid high inflation, currently close to $30 \%$.

By law, institutions cannot save money by lowering workers' pay or by laying off staff. Because salaries make up roughly $80 \%$ of a Venezuelan university's annual spending, reductions must come from the remaining $20 \%$. So institutions are seeing their library subscriptions and lab supplies cut back. Purse strings are likely to become even tighter in the coming months because the decree was signed after firstquarter budgets had been spent.

Yet the government claims that investment in science is growing (see page 1021). In a

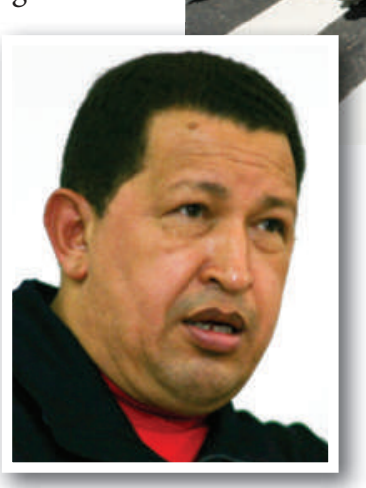

press conference on 3 June, science minister Jesse Chacón Escamillo said that Venezuela invests three times more in science and technology than any country in Latin America. He claimed that spending jumped from its typical level of $0.4 \%$ of gross domestic product to $1.7 \%$ in 2006 and about $2.7 \%$ in 2007.

"It is absolutely false," counters Claudio Bifano, president of the Venezuelan Academy of Physical, Mathematical, and Natural Sciences in Caracas. "It is political propaganda." On 11 June, Bifano and about a dozen university heads met to organize a study into the minister's claims. Findings are due in November.

Academic institutions can also get funding through an innovation, science and technology law, which since 2006 has required private companies to spend between $0.5 \%$ and $2 \%$ of their gross income on in-house research and development, or to give the money to an academic institution. Last year, Simón Bolívar University in Caracas received 62 million bolivars (US\$29 million) this way, but how the money has been apportioned remains obscure

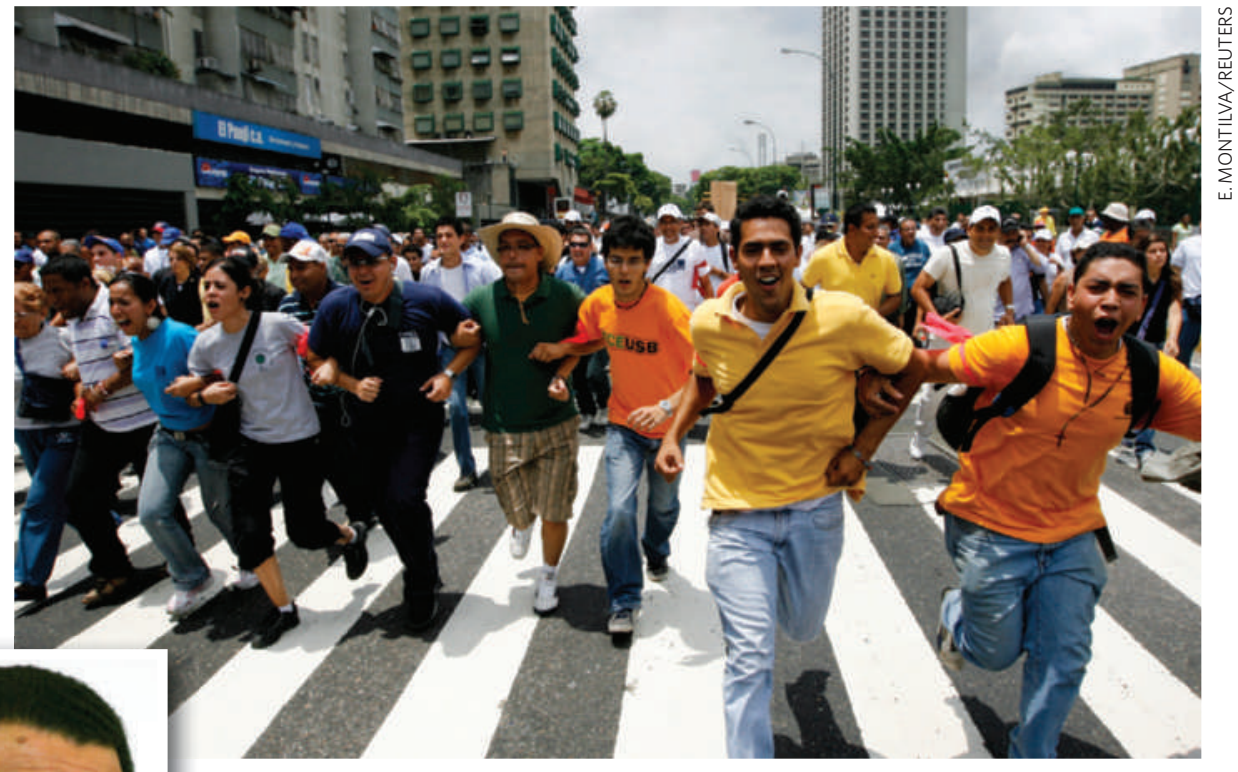

Cutbacks have sparked protests in Caracas against President Hugo Chávez (inset).

even to Benjamín Scharifker, the institution's chancellor. "There is a tremendous lack of accountability and transparency," he says. "We don't have any reports about the success of such grants - not even information about who are the people responsible for the projects."

Such funds are increasingly administered by government officials with military rather than science backgrounds. For example, Chacón, who declined to answer Nature's questions, was a lieutenant who was involved in Chávez's 1992 failed coup attempt. "When you have people who are used to giving orders and obeying orders, it's not easy for scientists to have an open environment and to get on with our work the way we think we should do it," says Scharifker.

Not everyone is unhappy, points out Orlando Albornoz, a sociologist at the Central University of Venezuela, Caracas: "Some people believe in the government and share their views." Still, many researchers worry that academic freedom is under threat. Two months ago, scientists at both the Venezuelan Institute for Scientific Research and the Foundation Institute of Advanced Studies (IDEA) in Caracas were instructed that they could not make public statements about their work without prior written consent from the directors of their institutions. "You have no chance of finding a position if you are considered an opponent [to Chávez] or if your name appears on a 2004 petition calling for him to go," says Luis Carbonell, president of the Venezuelan Association for the Advancement of Science's human-rights commission.

Venezuela's scientific workforce seems to have voted with its feet. In 2000, fewer than 3,000 Venezuelan scientists were registered as living in the United States; in 2008, that figure was roughly 9,000 . About the same number has moved to the European Union. Some of these emigrant scientists are from the 800 researchers that the government dismissed from the Venezuelan Institute of Petroleum Research in 2003 , following a national strike. Roughly 6,000 scientists remain in Venezuela.

Several lay-offs of prominent scientists have raised eyebrows recently. Jaime Requena, who had reviewed the country's scientific productivity, was fired in April from IDEA. Requena claims that he was wrongly denied a pension, wrongly accused of planning to make money from a software purchase, and that government officials told him last year they would find a way to fire him.

Like many others, Requena says that currency controls prevent international travel and collaboration. If "I am only allowed to spend $\$ 400$ a year on books from abroad”, he says, "how can I survive?"

Anna Petherick 